\title{
Regions of Ukraine: International and Retail Trade in 2016
}

\author{
Elena Kostenko ${ }^{1, *}$, Vitaly Kostenko ${ }^{2}$, Volodymyr Kuznichenko ${ }^{3} \&$ Volodymyr Lapshyn ${ }^{3}$ \\ ${ }^{1}$ Strategic Ampersand Inc., 1235 Bay Street, Suite 400, Toronto M3R 3K4, Canada \\ ${ }^{2}$ Biochem Environmental Solutions Inc. 91 Milvan Drive, Toronto M9L 1Z7, Canada \\ ${ }^{3}$ Department of mathematical methods in economics and information technologies, Kharkiv \\ Institute of Finances USUFIT, 5 Pletnivs'ky Lane, Kharkiv 61003, Ukraine \\ *Corresponding author: Strategic Ampersand Inc., 1235 Bay Street, Suite 400, Toronto M3R \\ 3K4, Canada. Tel: 1-416-961-5595 ext.407. E-mail: elena@stratamp.com
}

Received: November 19, 2017 Accepted: November 28, 2017 Published: December 20, 2017

doi: 10.5296/rae.v9i4.12163 URL: https://doi.org/10.5296/rae.v9i4.12163

\begin{abstract}
International trade in Ukraine's regions during 2016 is analyzed. The taxonomy method is used to carry out a multidimensional analysis of the state of trade in all regions, with the goal of determining their attractiveness with respect to investment and international cooperation. Key indicators were chosen to be: export and import of services, export and import of goods, balance of the trade of services, balance of the trade of goods, and retail trade. Using the standardized matrix of statistical values, provided by Ukraine's national statistics agency, the level of development of each region was determined, as well as its rating. A comparison of this year's ratings with those of the previous two years is carried out. Based on the calculated inter-regional distance matrix, calculated in the context of the seven chosen parameters, nonlinear structures of regional connections are constructed. Using them, clusters of regions can be constructed that take into account trade dynamics and other economic activity. The constructed linear and nonlinear connection structure of Ukraine's regions can become the basis of fruitful cooperation in the area of trade. They can also be used when carrying out mutual investment projects and when regulating the exchange of goods between Ukraine's regions. The determination of the regions' ratings and the nonlinear structures of their trade relations can provide valuable information to investors both foreign and domestic.
\end{abstract}

Keywords: trade, region, taxonomy method 


\section{The Nature of the Problem}

Trade is an important component of the socioeconomic development of countries, and plays a significant role in the integration of these countries into international society.

A country's overall volumes of import and export are important indicators, but it is their regional distribution that really defines their input into foreign trade. The level of retail trade is indicative of that region's potential to sell products.

The region is an integral part not only of the administrative and territorial structure of the country, but also of its overall economic structure. The study and analysis of retail sales indicators, the export and import of goods and services region-by-region, and comparisons with previous years is an important problem, especially for Ukraine, which is currently radically changing its economic policy. Determining the ratings of regions, the nonlinear structures of trade relations, which are the bases of cluster formation, offers important information to national and foreign investors. This information is now more important than ever, when the possibilities of trade are ever-expanding. The Ukraine-EU Free Trade Agreement went into action on January $1^{\text {st }}, 2016$. In May of 2017, the Ukraine-Canada Free Trade Agreement was ratified. All of the obstacles to the ratification of the Ukraine-EU Association Agreement have been removed.

\section{Analysis of Recent Studies and Publications}

The 20th century English economist John Hobson, along with many other scientists, drew attention to the incredibly important role that international trade played in a country's economy. He believed that a nation and a country progress only when the growth and volume of its international trade is greater than that of its internal trade. In the modern era of globalization, the role that international trade plays in countries' economies is greater than it's ever been.

The analyses that were carried out (Agrawal P.) showed that the speed of growth of export played a significant role in increasing the economy's growth rates in India after the 1991 reforms. Looking at Mexico and Argentina, Peluffo A. showed that the rise in export in countries of intermediate economic profits does not lead to an increase of demand for skilled labour. Earlier, it was stated that countries with high economic profits show increased demand for skilled labour when the export grows. An analysis of the business-cyclic synchronization between 21 pairs of EU countries over the period of 1998-2011 was carried out (Asteriou D., Moudastou A.). It determined and assigned value to the relations between the trade of goods and direct foreign investments.

A new index of diversification, the "Internal Diversification Index" (IDI), which characterizes the expansion of types of produced commodities for retail trade, is constructed and presented for empirical purposes by Kenan. The index values show that as countries become richer, their level of internal diversification increases.

According to the World Trade Statistical Review, the members of the WTO account for about 
98.2\% of the world's commodity trading. Asia, Europe and North America account for 88\% of this total. Between 2006 and 2016, the merchandise trade carried out by WTO members has increased from 11.7 trillion USD to 15.4 trillion USD. World exports of agricultural products increased by an average of 5\% per year. World exports of manufactured goods increased from 8 trillion USD in 2006 to 11 trillion USD in 2016. World exports of commercial services totaled 4.8 trillion USD in 2016, up from 2.9 trillion USD in 2006. The European Union and the North American Free Trade Agreement Zone continue to be the dominant regional trade agreements. Trade within the EU represented $63 \%$ of all EU total exports in 2015.

The efficiency of the United States' Free Trade Agreements is examined by Andreas. The United States has entered into Free Trade Agreements with 20 countries. A comparative analysis of trade growth showed that these agreements had a relatively small effect on the United States' exports.

Analyses based on data from 2003-2014 and the modified Sachs-Warner model showed that the indicators of export and import of natural resources and socioeconomic development do not correlate for all regions in Ukraine (Krivoruchko M.).

Mazaraki A., Melnik T. and Iksarova N. demonstrated the results of a complex analysis of the conditions and tendencies of development of modern Ukraine's external trade relations. The effects of exogenic and endogenic determinants on the dynamics and structure of foreign trade are demonstrated. The sectoral and geospatial components of Ukraine's foreign trade relations are analysed. A scientific grounding is given to the conceptual principles and mechanisms of the structural changes of Ukraine's foreign trade relations. The functioning and dynamics of the internal market and trade, the economic content and the control mechanisms, and also the regulation of internal trade during the national economy's modern period of development in the context of globalization is explored in the monographs (Mazaraki A., Lagutin V., Gerasimenko A., Umantsev Yu.). Special attention is paid to the economic, financial and institutional/organizational analysis of the transformation of internal trade, as well as the regulation of competitive relationships on the internal market.

After the signing of the EU association agreement, Ukraine's ability to participate in foreign trade with its European trading partners has increased substantially, despite the global demand for Ukraine's key export goods remaining low (Bilorus O., Gavrilyuk O.).

The results of the analysis of the state of Ukraine's foreign trade for the period of 2007-2015 that focused on regional aspects and groups of goods, demonstrated changes in the relative importance of the priority-level partners in the overall export-import picture, in accordance with the geopolitical interests of the government (Pyankova O., Ralko O.). In addition, attention was paid to negative tendencies with respect to the volume of trade and to the issues related to the diversification of export and import. It was noted that despite the significant drop in its overall export-import role, the Russian Federation remains Ukraine's largest trading partner (12.7\% of export and $20 \%$ of import); some of the priority-level exporters are Turkey, China, and Egypt, while some of the priority-level importers are Germany, China, and Belarus. 
According to Ukraine's national statistics agency, a comparison of the 2016 and 2015 totals showed that the volume of bilateral trade of goods between Ukraine and Canada increased by $4 \%$, mainly due to the import from Canada into Ukraine, and came out to 246 million 184 thousand USD. The export of goods from Ukraine to Canada dropped by $4 \%$ and came out to 28 million 890 thousand USD. The import of goods from Canada to Ukraine rose by $5 \%$ and came out to 217 million 294 thousand USD. The balance of the bilateral trade of goods was negative for Ukraine - 188 million 404 thousand USD. We note that the export of Ukrainian goods to Canada makes up just $0.08 \%$ of the total export, while the import of Canadian goods to Ukraine comes out to around $0.55 \%$ of the total import (Ministry report 2017).

Over the first 9 months of 2016, according to the national statistics agency, the volume of bilateral trade of services between Ukraine and Canada came out to 95 million USD. The export of services from Ukraine to Canada, compared to the analogous 2015 period, rose by $17.6 \%$ and came out to 58 million 779 thousand USD. The import of services from Canada to Ukraine rose by $11.9 \%$ and came out to 36 million 243 thousand USD. The balance of the bilateral trade of services for this period was positive for Ukraine and came out to 22 million 536.5 thousand USD.

According to the US Commission on International Trade, the total volume of trade between Ukraine and the USA for 2016 dropped by $5.4 \%$ (by 57.4 million USD) compared to 2015 and came out to 1655.5 million USD. The deficit of the bilateral trade is currently 500.5 million dollars. At the same time, the export of Ukrainian goods to the USA dropped by $32.1 \%$ (by 273.3 million USD), and came out to 577.5 million dollars. At the same time, the import of American goods into Ukraine rose by $25 \%$ (by 215.9 million dollars), and came out to 1078 million dollars. According to Ukraine's national statistics agency, the USA provided 85.2 million dollars of foreign investment in 2016, which came out to $1.9 \%$ of all direct foreign investment that Ukraine received, and that puts them in 11th place in terms of foreign investment into Ukraine (The Russian Federation invested 1667 million USD into Ukraine in 2016, which came out to $37.8 \%$ of all direct foreign investment).

The taxonomical method is used to carry out a multidimensional analysis of the state of international trade in Ukraine's regions in 2015 (Lapshin V., Kuznichenko V.). The key characteristics of these objects were chosen to be: export/import of goods, export/import of services, the balance of the trade of goods, and the balance of the trade of services. These economic parameters are used to determine the development indicators of each region and their rating. Nonlinear structures of the trading relations between regions are constructed, which can be used to form clusters of regions with similar levels of development.

\section{The Goal}

The goal of the present work is the calculation of the development indicators and ratings of each region in Ukraine, as well as the construction of inter-regional nonlinear trading relation structures based on the economic indicators of external and internal trade in 2016 to determine their attractiveness from an investment and foreign trade perspective. 


\section{Main Results of the Analysis}

For an integral analysis of the trade process in Ukraine's regions, let's apply the method of multidimensional comparative analysis - the taxonomy method (Plyuta V.). The first step in the taxonomical procedure is the creation of an observation matrix. Using statistical data from Ukraine's national Statistics Agency for 2016, we construct a 25x7 matrix (table), where the rows denote regions (in Cyrillic alphabetical order, except for Kyiv City, which is listed last), and the columns denote their characteristics, namely: export and import of services, export and import of goods, balance of the trade of services, balance of the trade of goods, and retail trade respectively. The symbol $x_{i k}$ denotes the value of the characteristic $k$ for the unit $i$, where $i=\overline{1,25}$ is the number of the region-unit and $k=\overline{1,7}$ is the number of the characteristic.

The standardization of the characteristics is done according to the formulas found on page 11 (Lapshin V., Kuznichenko V.) ( $z_{i k}$ is the standardized value of the characteristic $k$ for the unit $i$ ). The standardized matrix (table) looks like the following:

Table 1. Standardized Matrix of Statistical Trade Indicators in Ukraine's Regions for 2016

\begin{tabular}{ccccccccc}
\hline № & $\begin{array}{c}\text { Region of } \\
\text { Ukraine }\end{array}$ & $\begin{array}{c}\text { Export } \\
\text { of } \\
\text { services }\end{array}$ & $\begin{array}{c}\text { Import } \\
\text { of } \\
\text { services }\end{array}$ & $\begin{array}{c}\text { Export } \\
\text { of goods }\end{array}$ & $\begin{array}{c}\text { Import } \\
\text { of goods }\end{array}$ & $\begin{array}{c}\text { Service } \\
\text { balance }\end{array}$ & $\begin{array}{c}\text { Goods } \\
\text { balance }\end{array}$ & $\begin{array}{c}\text { Volume } \\
\text { of retail }\end{array}$ \\
\hline 1 & Vinnytsia & $-0,345$ & $-0,311$ & $-0,247$ & $-0,377$ & $-0,294$ & 0,165 & $-0,248$ \\
2 & Volyn & $-0,375$ & $-0,313$ & $-0,442$ & $-0,120$ & $-0,368$ & $-0,513$ & $-0,502$ \\
3 & Dnepr & $-0,135$ & 0,451 & 2,329 & 0,636 & $-1,303$ & 1,145 & 1,669 \\
4 & Donetsk & 0,208 & 0,078 & 1,045 & $-0,116$ & 0,402 & 1,087 & $-0,241$ \\
5 & Zhitomir & $-0,392$ & $-0,317$ & $-0,510$ & $-0,365$ & $-0,411$ & $-0,137$ & $-0,425$ \\
6 & Zakarpattia & $-0,115$ & $-0,291$ & $-0,126$ & $-0,109$ & 0,290 & $-0,176$ & $-0,529$ \\
7 & Zaporozhye & $-0,148$ & $-0,217$ & 0,444 & $-0,152$ & 0,048 & 0,509 & 0,244 \\
8 & Ivano- & $-0,367$ & $-0,313$ & $-0,463$ & $-0,343$ & $-0,352$ & $-0,126$ & $-0,232$ \\
& Frankivsk & & & & & & \\
9 & Kyiv & $-0,0669$ & 0,159 & 0,134 & 0,477 & $-0,512$ & $-0,923$ & 0,344 \\
10 & Kirovograd & $-0,419$ & $-0,312$ & $-0,540$ & $-0,415$ & $-0,493$ & $-0,083$ & $-0,589$ \\
11 & Luhansk & $-0,404$ & $-0,215$ & $-0,535$ & $-0,359$ & $-0,655$ & $-0,176$ & $-1,008$ \\
12 & Lviv & 0,306 & $-0,185$ & $-0,092$ & 0,0737 & 1,215 & $-0,459$ & 0,585 \\
13 & Mykolayiv & 0,351 & $-0,209$ & 0,114 & $-0,253$ & 1,390 & 0,332 & $-0,377$ \\
14 & Odessa & 1,045 & $-0,015$ & 0,0370 & $-0,077$ & 2,877 & $-0,057$ & 1,018 \\
15 & Poltava & $-0,414$ & 0,015 & $-0,008$ & $-0,202$ & $-1,158$ & 0,114 & $-0,314$ \\
16 & Rivne & $-0,415$ & $-0,317$ & $-0,597$ & $-0,392$ & $-0,473$ & $-0,185$ & $-0,540$ \\
17 & Sumy & $-0,423$ & $-0,287$ & $-0,479$ & $-0,333$ & $-0,558$ & $-0,161$ & $-0,556$ \\
18 & Ternopil & $-0,390$ & $-0,342$ & $-0,610$ & $-0,385$ & $-0,352$ & $-0,209$ & $-0,647$ \\
19 & Kharkiv & 0,0479 & $-0,201$ & $-0,223$ & 0,006 & 0,547 & $-0,481$ & 1,334 \\
20 & Kherson & $-0,410$ & $-0,344$ & $-0,635$ & $-0,420$ & $-0,404$ & $-0,175$ & $-0,453$ \\
21 & Khmelnitsky & $-0,434$ & $-0,332$ & $-0,597$ & $-0,367$ & $-0,492$ & $-0,228$ & $-0,469$ \\
22 & Cherkassy & $-0,436$ & $-0,301$ & $-0,515$ & $-0,380$ & $-0,562$ & $-0,117$ & $-0,436$ \\
23 & Chernivtsi & $-0,432$ & $-0,353$ & $-0,702$ & $-0,443$ & $-0,443$ & $-0,207$ & $-0,747$ \\
24 & Chernihiv & $-0,433$ & $-0,336$ & $-0,537$ & $-0,321$ & $-0,482$ & $-0,244$ & $-0,602$ \\
25 & Kyiv City & 4,594 & 4,808 & 3,756 & 4,725 & 2,544 & $-4,487$ & 3,720 \\
\hline & & & & & & & & \\
\hline
\end{tabular}




\section{Macrothink}

Using the standardized matrix, let's find the development indicators of the chosen objects (regions). For this, we will construct a unit of development, which will have seven coordinates (one for each characteristic): $z_{01}, z_{02}, z_{03}, z_{04}, z_{05}, z_{06}, z_{07}$. These coordinates are determined in the following way:

$$
\begin{array}{ll}
z_{0 k}=\max _{r} z_{r k}, & k \in I, \\
z_{0 k}=\min _{r} z_{r k}, & k \notin I
\end{array}
$$

where $k$ is the number of the indicator, and $I$ is the number of stimulator indicators, which include the indicators that have a positive, stimulating effect on the objects' level of development. Other indicators, which have a negative effect on the objects, are called destimulators. In our analysis, all of the indicators can be taken to be stimulators. The unit of development (the unit-region of trade), in terms of the 7 chosen indicators, has the following coordinates:

$$
P_{0}\left(z_{01}=4.5941 ; z_{02}=4.8082 ; z_{03}=3.7557 ; z_{04}=4.7255 ; z_{05}=2.5438 ; z_{06}=1.1446 ; \cdot z_{07}=3,7199\right)
$$

The distance between separate point-objects and the point $P_{0}$, which represents the unit of development, is denoted by $c_{i 0}$, and is calculated in the following way:

$$
c_{i 0}=\left[\sum_{k=1}^{7}\left(z_{i k}-z_{0 k}\right)^{2}\right]^{1 / 2}, \quad i=\overline{1,25}
$$

The obtained distances determine the region's level of development:

$$
d_{i}^{*}=\frac{c_{i 0}}{c_{0}}
$$

where $c_{0}$ is a normalization constant, which is calculated using the values of $c_{i 0}$.

The results of the calculations of the trade development levels for Ukraine's regions (linear structural relations) for 2014, 2015 and 2016 are provided in Table 2. The lower the level, the closer the region is to the unit of development (the unit-region of trade).

We would like to note that in 2014 and 2015, the volume of retail was not taken into account in the calculation of the regional trade development level. This could be one of the reasons for the significant position change two regions saw: Luhansk moved up thirteen points, while Poltava fell thirteen points. 
Table 2. Trade Development Levels of Ukrainian Regions (developed by the authors)

\begin{tabular}{|c|c|c|c|c|c|}
\hline \multirow[b]{2}{*}{ Region } & \multirow{2}{*}{$\frac{2014}{d_{i}}$} & \multicolumn{3}{|c|}{2015} & \multirow{2}{*}{$\frac{2016}{d_{i}}$} \\
\hline & & Region & $d_{i}$ & Region & \\
\hline Dnepr & 0,550 & Kyiv City & 0,5134 & Kyiv City & 0,43931 \\
\hline Donetsk & 0,624 & Odessa & 0,7117 & Dnepr & 0,69388 \\
\hline Kyiv City & 0,747 & Dnepr & 0,7242 & Odessa & 0,70476 \\
\hline Zaporozhye & 0,749 & Donetsk & 0,7383 & Donetsk & 0,75092 \\
\hline Poltava & 0,814 & Mykolayiv & 0,7713 & Lviv & 0,75609 \\
\hline Kyiv & 0,819 & Lviv & 0,7911 & Kharkiv & 0,76509 \\
\hline Kharkiv & 0,820 & Zaporozhye & 0,8000 & Kyiv & 0,77820 \\
\hline Odessa & 0,822 & Kyiv & 0,8089 & Mykolayiv & 0,78010 \\
\hline Luhansk & 0,823 & Kharkiv & 0,8098 & Zaporozhye & 0,78484 \\
\hline Mykolayiv & 0,831 & Zakarpattia & 0,8317 & Vinnytsia & 0,80642 \\
\hline Lviv & 0,842 & Poltava & 0,8583 & Zakarpattia & 0,82377 \\
\hline Zakarpattia & 0,842 & Vinnytsia & 0,8647 & Luhansk & 0,84580 \\
\hline Kirovograd & 0,876 & Volyn & 0,8717 & Ivano-Frankivsk & 0,85437 \\
\hline Volyn & 0,877 & Sumy & 0,8799 & Volyn & 0,85800 \\
\hline Sumy & 0,877 & Ivano-Frankivsk & 0,8810 & Zhitomir & 0,86449 \\
\hline Vinnytsia & 0,878 & Zhitomir & 0,8821 & Cherkassy & 0,86950 \\
\hline Chernihiv & 0,879 & Chernihiv & 0,8824 & Sumy & 0,86965 \\
\hline Zhitomir & 0,882 & Ternopil & 0,8838 & Kherson & 0,87287 \\
\hline Cherkassy & 0,883 & Khmelnitsky & 0,8854 & Khmelnitsky & 0,87297 \\
\hline Ivano-Frankivsk & 0,888 & Kirovograd & 0,8855 & Chernihiv & 0,87356 \\
\hline Khmelnitsky & 0,889 & Cherkassy & 0,8858 & Rivne & 0,87398 \\
\hline Rivne & 0,890 & Rivne & 0,8867 & Kirovograd & 0,87402 \\
\hline Ternopil & 0,895 & Kherson & 0,8893 & Ternopil & 0,87509 \\
\hline Kherson & 0,896 & Chernivtsi & 0,8942 & Poltava & 0,88541 \\
\hline Chernivtsi & 0,906 & Luhansk & 0,8977 & Chernivtsi & 0,88670 \\
\hline
\end{tabular}

The relations between regions in terms of their level of development is clearly seen in the nonlinear structure (dendrit). Let's build this structure for Ukraine's regions in the context of the seven standardized parameters that define the state of the trade process. To do this, we need to use data from table 1 and find the distance between unit-regions in terms of the chosen parameters, in accordance with the formula from page 12 (Lapshin, V., Kuznichenko, V.):

$$
c_{r s}=\left[\frac{1}{7} \sum_{k=1}^{7}\left(z_{r k}-z_{s k}\right)^{2}\right]^{1 / 2},
$$

where $r$ is the line number and $s$ is the column number of the distance matrix. The distance matrix is 25 by 25 , and has zeroes along its diagonal. 


\section{Macrothink}

The construction of the optimal dendrit comes down to finding relations between the units that differ the least from one another, and consists of several steps. In the first step, we take the composed distance matrix and separate out the smallest distances between units (calculated in terms of the chosen parameters). In the end, one gets separate constructs, called first order unifications. These unifications do not meet the key requirements of the dendrit they are not bound together into one whole. To meet this demand, one takes the lowest distance between the units that enter into different first order unifications. This corresponding interval becomes the relation between the two unifications. In the end, one obtains second order unifications. The dendrit determines the relation between specific unifications of all orders.

Figure 1 demonstrates the first order unifications. The number in the circle denotes the number of the region (see table 1), while the numbers above the relations between them denote the standardized distances between the unit-regions in terms of the chosen parameters.

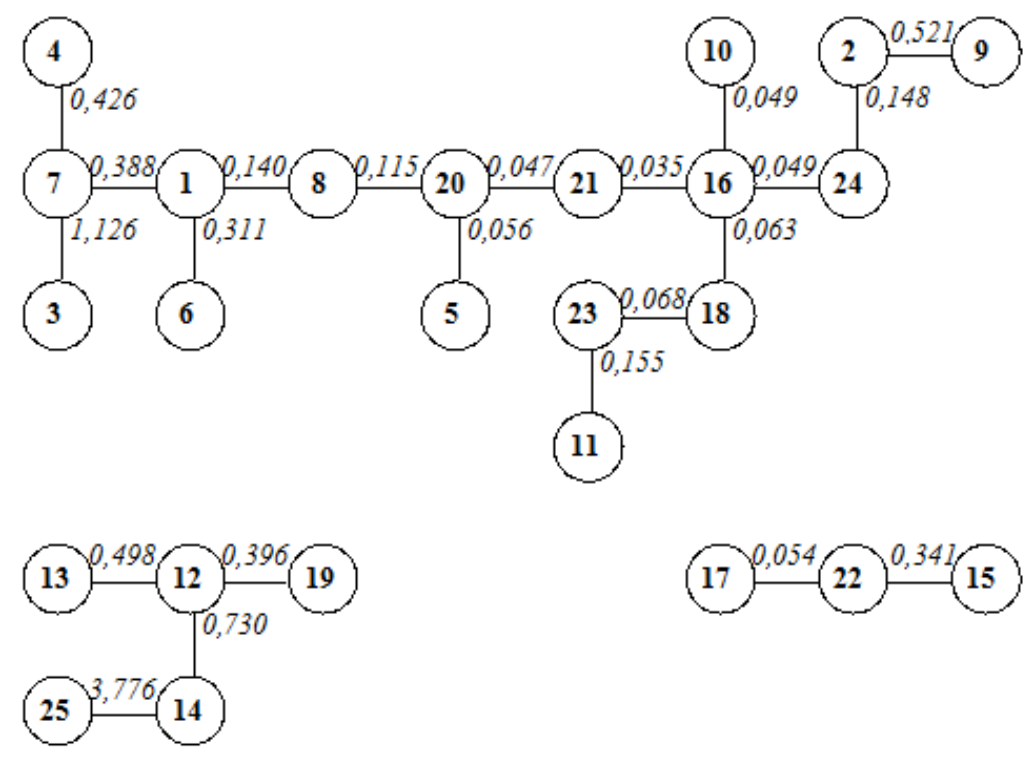

Figure 1. Structures of First Order Unifications of the Relations between Ukraine's Regions in 2016

The nonlinear structure (dendrit), which unifies the regions in terms of the seven chosen trade parameters, is presented in Figure 2.

The regions closest to each other in terms of international and retail trade in the region are: Khmelnitsky, Rivne, Kherson, Kirovograd, Chernihiv, Sumy, Cherkassy, Zhitomir and Chernivtsi ; Vinnytsia, Ivano-Frankivsk and Zakarpattia; Lviv, Kharkiv, Mykolayiv, Odessa; Donetsk, Zaporozhye, Dnepr; The most near connections have in relation to other regions: Kyiv, Volyn; Poltava, Cherkassy; Luhansk, Chernivtsi; Volyn, Chernihiv.

The nonlinear structure is the basis for the formation of clusters, which unite regions with similar trade parameters. It is recommended that clusters be formed out of the regions that are closest to each other. We also believe that it is useful to consider first-order clusters, which connect into groups structures composed of two units with minimal distances between each other. 


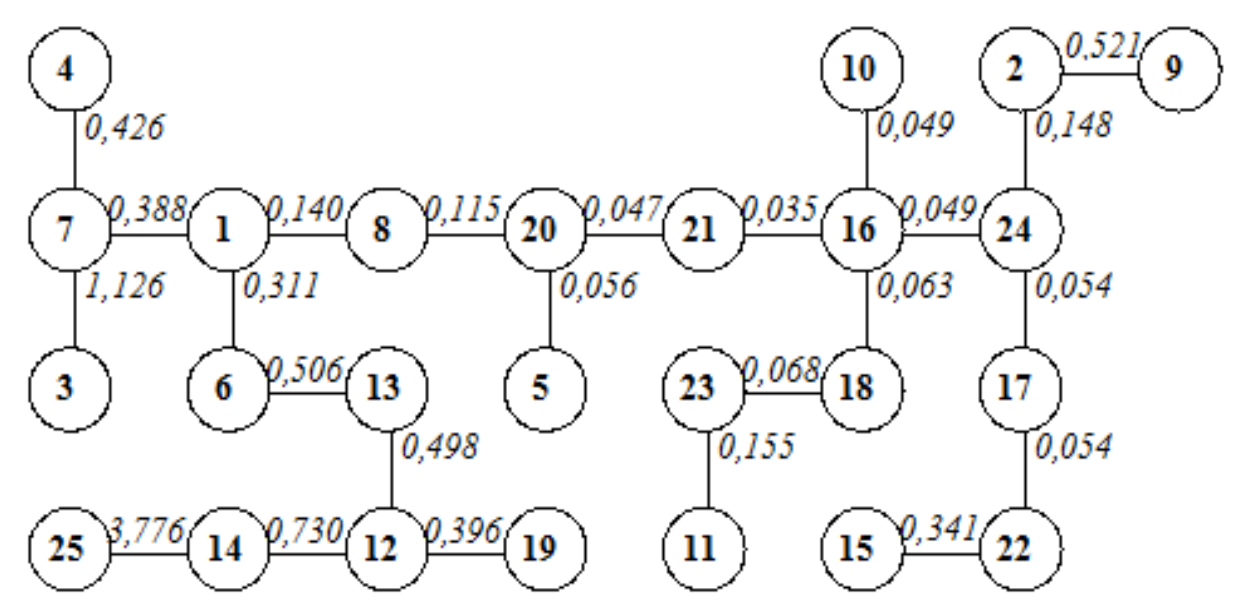

Figure 2. The Nonlinear Connection Structure of Ukraine's Regions in 2016

Thanks to the adjacency of the trade parameters, clusters simplify the trade process planning system, and also help define the priority tasks and regional investment vectors.

\section{Conclusion}

Linear and nonlinear connection structures of Ukraine's regions are developed, which can become the basis of fruitful cooperation in the area of trade. They can also be used when carrying out mutual investment projects and when regulating the exchange of goods between Ukraine's regions. When forming clusters, we suggest that one finds an optimal mix of the analysis of linear connection structures (the regional trade development indicators) and of nonlinear connection structures; that one gradually cut off the longest inter-regional distance; that one takes into account first order clusters; and that one also takes into account the geographical positions of the regions.

Ukraine can become a reliable trading partner to both the EU and to Canada, who have everything necessary to effectively, in a mutually beneficial manner, integrate Ukraine's regions into their markets. The Free Trade Agreement with Canada, which along with the USA and Mexico comprises NAFTA, presents Ukraine with the opportunity to expand its trade relations with these countries as well. The above analysis is also of interest to those seeking to invest in Ukraine's regions.

\section{References}

Agrawal, P. (2014). The roles of exports in Indian's economic growth. The Journal of International Trade and Economic Development, 24, 1-25. https://doi.org/10.1080/09638199.2014.968192

Andreas, U. (2017). The United States Free Trade Agreements: How Successful Have They 


\section{$\Lambda$ Macrothink}

Been? The International Trade Journal, 31(5), 457-478. https://doi.org/10.1080/08853908.2017.1362365

Asteriou, D., \& Moudastou, A. (2015). Business Cycle Synchronization in the Enlarged EU: The Role of Bilateral Trade and FDI. Review of Development Economics, 19(1), 196-207. https://doi.org/10.1111/rode.12134

Bilorus, O., \& Gavrilyuk, O. (2015). Strategic imperatives of the adaptation of Ukraine's international trade in the context of European integration. Economic of Ukraine, 11, 4-15.

Government of Ukraine, (2017). Ministry of Foreign Affairs of Ukraine 2017. Retrieved from http://www.canada.mfa.gov.ua/ua/ukraine-ca/trade

Government of Ukraine, (2017). Ministry of Foreign Affairs of Ukraine 2017. Retrieved from http://www.usa.mfa.gov.ua/ua/ukraine-us/trade

Government of Ukraine, (2017). State Statistics Service of Ukraine 2017. Retrieved from http://www.ukrstat.gov.ua

Hobson, J.A. (2003). International Trade: An Application of Economic Theory. Kitchener: Batoche Books. p. 76.

Kenan, B. (2016). Measuring within Diversification. The International Trade Journal, 30(3), 223-236. https://doi.org/10.1080/08853908.2016.1138911

Krivoruchko, M. (2015). Resource orientation of export and import as a factor of the socioeconomic development of Ukraine's regions. Business Inform, 9, 112-122.

Lagutin, V., Umantsev, Yu., \& Gerasimenko, A. (2015). Internal market and trade in Ukraine. Kyiv: KNTEU. p. 432.

Lapshin, V., \& Kuznichenko, V. (2016). International trade activity of Ukraine's regions. International trade: economic, finance, law, 2(85), 54-64.

Mazaraki, A., Lagutin, V., \& Gerasimenko, A. (2016). Internal trade in Ukraine. Kyiv: KNTEU. p. 864.

Mazaraki, A., Melnik, T., \& Iksarova, N. (2016). Ukraine's international trade: XXI century. Kyiv: KNTEU. p. 600.

Peluffo, A. (2015). Foreign Direct Investment, Productivity, Demand for Skilled Labor and Wage Inequality: An Analysis of Uruguay. The World Economy, 38(6), 962-983. https://doi.org/10.1111/twec. 12180

Plyuta, V. (1980). Comparative multidimensional analysis in economic analyses: methods of taxonomy and factor analysis. Moscow: Statistics. p. 151.

Pyankova, O., \& Ralko, O. (2016). Ukraine's international trade: the problematics of structural changes and priorities. Economics and Society, 5, 65-71.

World Trade Organization. (2017). World Trade Statistical Review. Retrieved from 
https://www.wto.org/english/res_e/statis_e/wts2016_e/wts16_toc_e.htm

\section{Copyright Disclaimer}

Copyright for this article is retained by the author(s), with first publication rights granted to the journal.

This is an open-access article distributed under the terms and conditions of the Creative Commons Attribution license (http://creativecommons.org/licenses/by/3.0/). 